\section{After-ripening, Stratification, and Perigynia Removal Enhance Pennsylvania Sedge Germination}

\author{
Esther E. McGinnis ${ }^{1}$ and Mary H. Meyer
}

AdDitional INDEX words. Carex pensylvanica, dormancy, propagation, Cyperaceae, achene

Summary. Pennsylvania sedge (Carex pensylvanica) has horticultural and restoration potential, but the achenes are difficult to germinate due to complex dormancy requirements. This study identified treatments to overcome physiological dormancy and determined light and temperature requirements for optimum germination. We first tested the effects of perigynia removal and light on achene germination. In the second experiment, achenes were subjected to varying durations of dry-cold or dry-warm storage conditions and a presowing soak in gibberellic acid $\left(\mathrm{GA}_{3}\right)$. In a third experiment, we studied whether storage conditions, cold stratification, and sowing temperatures affected germination. Pennsylvania sedge germination was improved by dry-warm storage, perigynia removal, cold stratification, and germination in light.

$\mathrm{P}$ ennsylvania sedge is commonly used for forest restoration (Mottl et al., 2006) and has horticultural potential as a shade-tolerant groundcover and low-maintenance lawn species (Darke, 2007). This herbaceous perennial is native to dry deciduous forests of the eastern half of temperate North America (Gleason and Cronquist, 1991). It produces attractive slender leaves that form a 12 -inch mound of foliage that expands through long and short rhizomes (Bernard, 1990) to form mats of $3 \mathrm{~m}^{2}$ (Mottl et al., 2006). Unlike most lawn species, it thrives in dry partial shade and is uniquely suited to the competitive environment under large trees. Pennsylvania sedge also provides spring interest because it blooms in mid-April to mid-May in southern Ontario and in the northern United States (Crins and Ball, 1983). Achenes ripen and dehisce in June in Minnesota (Table 1). Difficulties in achene germination limit the use of pennsylvania sedge for large horticultural and restoration projects. No germination protocol has been

Department of Horticultural Science, University of Minnesota, 305 Alderman Hall, 1970 Folwell Avenue, St. Paul, MN 55108

We thank Alan Wade from Prairie Moon Nursery, Winona County, MN, for donating achenes and plant material for this experiment.

Mention of a trademark, proprietary product, or vendor does not imply endorsement by the University

of Minnesota or its approval to the exclusion of other suitable products or vendors.

${ }^{1}$ Corresponding author. E-mail: mcgi0031@umn.edu. published, and native plant nurseries propagate plants by division. Overcoming dormancy and understanding germination requirements are essential for economically propagating pennsylvania sedge on a commercial basis.

Few Carex species exhibit physical dormancy or other germination barriers as a result of their unique morphology. Carex are distinguished from other genera within the Cyperaceae by a bladder-like sac called the perigynium (perigynia, plural) that tightly adheres to the hard pericarp of the achene (Amen and Bonde, 1964). The perigynium prevents germination in nebraska sedge (Carex nebrascensis) and northwest territory sedge (Carex utriculata) (Hoag et al., 2001; Jones et al., 2004). In other cases, Carex species respond to traditional physical dormancy treatments such as acidic scarification (Ishikawa et al., 1993) or pericarp nicking (Amen and Bonde, 1964). It is unknown whether pennsylvania sedge exhibits physical dormancy or other germination barriers.
Physiological dormancy is common in the Cyperaceae and may be overcome or reduced by one or more of the following treatments: 1) afterripening (dry storage of seeds under ambient temperatures before sowing), 2) $\mathrm{GA}_{3}$, and 3 ) cold stratification (Baskin and Baskin, 1998, 2004). Broom sedge (Carex scoparia) germination was enhanced by up to 2 years of after-ripening (Larson and Stearns, 1990). Elongated sedge (Carexelongata) and remote sedge (Carex remota) increased germination following afterripening in comparison with fresh achenes (Schutz, 1997b). However, some wetland Carex species had higher germination percentages when stored cold and moist (Budelsky and Galatowitsch, 1999).

Although $\mathrm{GA}_{3}$ failed to stimulate germination in black and white sedge (Carex albonigra), ebony sedge [Carex ebenea (Amen and Bonde, 1964)], and hood's sedge [Carex hoodii (McDonough, 1969)], it has been shown to increase germination for other monocots such as sand ryegrass [Leymus arenarius (Greipsson, 2001)], green needlegrass [Stipa viridula (Fulbright et al., 1983)], eastern gamagrass [Tripsacum dactyloides (Rogis et al., 2004)], and four Australian grass species (Hagon, 1976). In contrast to $\mathrm{GA}_{3}$ pretreatment, cold stratification has been shown to successfully alleviate physiological dormancy in many Carex species (Hoag et al., 2001; Kettenring and Galatowitsch, 2007a, b; Schutz and Rave, 1999). Although the most effective stratification temperatures for Carex species can vary, temperatures below $12{ }^{\circ} \mathrm{C}$ are most effective (Brandel and Schutz, 2005). Optimum stratification duration may range from 0.5 to 6 months for Carex species (Kettenring and Galatowitsch, 2007a).

Pennsylvania sedge may have additional germination requirements. A light requirement enables woodland Carex species to take advantage of gaps in leaf litter on the forest floor

\begin{tabular}{llll}
\hline $\begin{array}{l}\text { Units } \\
\text { To convert U.S. to SI, } \\
\text { multiply by }\end{array}$ & U.S. unit & SI unit & $\begin{array}{l}\text { To convert SI to U.S., } \\
\text { multiply by }\end{array}$ \\
\hline 0.0929 & $\mathrm{ft}^{2}$ & $\mathrm{~m}^{2}$ & 10.7639 \\
3.7854 & gal & $\mathrm{L}$ & 0.2642 \\
2.54 & inch $(\mathrm{es})$ & $\mathrm{cm}$ & 0.3937 \\
16.3871 & inch $^{3}$ & $\mathrm{~cm}^{3}$ & 0.0610 \\
1 & ppm & $\mathrm{mg}^{3} \mathrm{~L}^{-1}$ & 1 \\
$\left({ }^{\circ} \mathrm{F}-32\right) \div 1.8$ & ${ }^{\circ} \mathrm{F}$ & ${ }^{\circ} \mathrm{C}$ & $\left(1.8 \times{ }^{\circ} \mathrm{C}\right)+32$
\end{tabular}


Table 1. Origin and collection month of ripe pennsylvania sedge achenes used in University of Minnesota germination experiments, 2005 and 2006.

\begin{tabular}{lcc}
\hline Location & Address & Collection mo. \\
\hline Prairie Moon Nursery & Section 15, Township 105N, Range 7W, & June 2005, 2006 \\
Wniversity of Minnesota, & Winona County, MN & June 2006 \\
Landscape Arboretum & Section 17, Township 116N, Range 23W, & Jarver County, MN \\
Lebanon Hills Regional Park & Sections 34 and 35, Township 27N, & June \\
Cedar Creek Natural History Area & Range 19W, Dakota County, MN & June 2006 \\
& Section 34, Township 34N, Range 23W, & Anoka County, MN \\
\hline
\end{tabular}

or in the deciduous forest canopy (Vellend et al., 2000). Germination of Carex species increased when imbibed achenes were exposed to white fluorescent light (Kettenring et al., 2006; Schutz and Rave, 1999). In a groundcover study, the frequency of pennsylvania sedge decreased under tree canopy compared with clearings (Collins and Good, 1987). Optimum germination temperature has not been identified for pennsylvania sedge. European temperate sedges typically require warm temperatures $\left(>28^{\circ} \mathrm{C}\right)$ for germination (Grimes et al., 1981). Schutz and Rave (1999) reported that a diurnally fluctuating temperature regime also enhances germination of some Carex species because this mimics spring temperatures. Alternating day and night temperatures of 27 and $15^{\circ} \mathrm{C}$ increased germination for unstratified achenes for the majority of 12 temperate North American wetland Carex species (Kettenring and Galatowitsch, 2007a).

The objectives of this project were to test whether pennsylvania sedge germination is enhanced by treatments designed to overcome germination barriers posed by the perigynia and by the physiological dormancy. In addition, we sought to determine optimum light and sowing temperatures. We hypothesized that achene germination would be improved by 1) perigynia removal, 2) presence of white light, 3) after-ripening, 4) $\mathrm{GA}_{3}$ pretreatment, 5 ) cold stratification, and 6) diurnally fluctuating temperatures.

\section{Materials and methods}

In 2005, Prairie Moon Nursery (Winona County, MN) provided freshly collected achenes (Table 1). In 2006, Prairie Moon Nursery could only provide $\approx 25 \%$ of the achenes required for the experiments; therefore, mature achenes were collected from three additional locations in Minnesota (Table 1). In both years, filled achenes were separated from unfilled achenes using an air column separator and tested for viability using a $1 \%$ solution of 2,3,5-triphenyltetrazolium chloride as described in Grabe (1970). Viability percentages ranged from $77 \%$ to $81 \%$ in both years. Because of the similarity of viability, 2006 achenes were combined. The total number of achenes per petri dish was multiplied by the estimated viability percentage, and this number was deemed to be the maximum possible germination per dish.

EXPT. 1: PERIGYNIA REMOVAL AND LIGHT EXPOSURE. This experiment was conducted in 2006 with achenes that had been stored dry at $\approx 22{ }^{\circ} \mathrm{C}, 50 \%$ relative humidity $(\mathrm{RH})$ for 8 weeks. The achenes were divided for the following four treatments: 1) intact perigynia, no light; 2) intact perigynia, exposure to white light; 3) removed perigynia, no light; and 4) removed perigynia, exposure to white light. Perigynia were removed by rubbing the achenes in a hand trough between two layers of hard dimpled rubber. The friction from the hand trough removed the perigynia but did not scarify the exterior of the achene. While light sanding with 100-grit sandpaper is an accepted method for removing perigynia (Hoag et al., 2001), pennsylvania sedge achenes crumble if they are lightly rubbed with sandpaper (E.E. McGinnis, unpublished data); therefore, scarification was not attempted.

Each $5.0 \times 1.2-\mathrm{cm}^{2}$ petri dish (Fisher Scientific, Pittsburgh, PA) was filled with $18.5 \mathrm{~cm}^{3}$ of sterilized fine quartz sand (Industrial Quartz; Unimin, LeSueur, MN). Fifteen achenes were placed on top of the sand in each dish. The sand was moistened with deionized water, and more water was added as needed. Four petri dishes (four replications) for a total of 60 achenes were assigned to each treatment. All four petri dishes were kept in a clear plastic bag (1 gal) to prevent excessive evaporation. The entire experiment was repeated 1 week later.

Achenes exposed to white light were placed in a growth chamber (Environmental Growth Chambers, Chagrin Falls, OH) and subjected to $200 \mu \mathrm{mol} \cdot \mathrm{m}^{-2} \cdot \mathrm{s}^{-1}$ of irradiance under cool white fluorescent bulbs (model F72T12/CW/VHO; Philips Lighting, Somerset, NJ) for $12 \mathrm{~h}$ per day, with alternating $26{ }^{\circ} \mathrm{C}, 10$-h days/ $18^{\circ} \mathrm{C}, 10$-h nights with a 2 -h transition period between temperatures. Achenes with no light exposure were placed in the same growth chamber, but petri dishes were double wrapped in aluminum foil to prevent light penetration. Germination counts were conducted daily or every second day for 8 weeks. Germinated seedlings were periodically removed. Counts for the dark treatments were made in a dark room under low intensity green light.

EXPT. 2: STORAGE TEMPERATURE, DURATION, AND GA $\mathbf{G}_{3}$. Experiment 2 was conducted in 2006 with achenes that were stored dry at $\approx 22{ }^{\circ} \mathrm{C}, 50 \%$ $\mathrm{RH}$ for 5 weeks. Achenes were further stored COLD $\left(4{ }^{\circ} \mathrm{C}, 8 \% \mathrm{RH}\right)$, or WARM, ( $\approx 22{ }^{\circ} \mathrm{C}, 40 \%$ average $\left.\mathrm{RH}\right)$ for an additional 4,8 , or 16 weeks. Thus, the total dry storage time was 9,13 , or 21 weeks. In addition to storage temperature and duration, a $\mathrm{GA}_{3}$ application constituted the third factor.

At the conclusion of the storage treatments, perigynia were removed as described in Expt. 1. Achenes were 
surface disinfected using a 30 -s soak in $10 \%$ chlorine bleach solution and then briefly rinsed, first in tap water and then in distilled water. (The previous experiment did not use bleach disinfection because it may have interfered with potential germination inhibitors in the attached perigynia.) After disinfection, one-half of the achenes were soaked for $24 \mathrm{~h}$ in 500 $\mathrm{mg} \cdot \mathrm{L}^{-1} \mathrm{GA}_{3}$ (ProGibb ${ }^{\circledR} \mathrm{T} \& \mathrm{O}$; Valent BioSciences, Libertyville, IL); the remaining $50 \%$ of the achenes were soaked in distilled water as the control. Using a $2 \times 3 \times 2$ factorial design, all treatment combinations were tested for final germination percentage. Four replications of 15 achenes each were assigned to each treatment, and the entire experiment was repeated in time 1 week later. Media, growth chamber conditions, and data collection are described in Expt. 1.

EXPT. 3: STORAGE, COLD STRATIFICATION, AND SOWING TEMPERATURE. This experiment was conducted in both 2005 and 2006 , using a $2 \times$ $3 \times 3$ factorial design. The first factor compared 5 months of storage, either 1 month WARM $\left(\approx 22{ }^{\circ} \mathrm{C}\right.$ and $50 \%$ $\mathrm{RH})$ followed by 4 months COLD $\left(4^{\circ} \mathrm{C}\right.$ and $\left.8 \% \mathrm{RH}\right)$ or 2 months WARM $\left(\approx 22{ }^{\circ} \mathrm{C}\right.$ and $\left.50 \% \mathrm{RH}\right)$ followed by 3 months COLD $\left(4^{\circ} \mathrm{C}\right.$ and $\left.8 \% \mathrm{RH}\right)$. Cold, moist stratification duration consisted of 0,1 , or 2 months. The final factor compared diurnally fluctuating temperatures with a constant sowing temperature: 1) $26^{\circ} \mathrm{C}$ day/ $18{ }^{\circ} \mathrm{C}$ night, 2) $30{ }^{\circ} \mathrm{C}$ day $/ 14{ }^{\circ} \mathrm{C}$ night, or 3 ) constant temperature of $22^{\circ} \mathrm{C}$.

Perigynia were removed, and achenes were disinfected. Cold stratification consisted of wrapping 15 or 30 achenes in filter paper and burying them in a container of SB 500 High Porosity Mix (Sun Gro, Vancouver, BC, Canada). Containers were watered to saturation and placed in a growth chamber at a constant $4{ }^{\circ} \mathrm{C}$ for 1 or 2 months. The control treatment was immediately sown on sand in petri dishes under conditions described below.

After stratification, achenes were sown in three separate growth chambers with day/night temperatures of $26{ }^{\circ} \mathrm{C} / 18{ }^{\circ} \mathrm{C}, 30{ }^{\circ} \mathrm{C} / 14{ }^{\circ} \mathrm{C}$, and constant $22^{\circ} \mathrm{C}$ with $200 \mu \mathrm{mol} \cdot \mathrm{m}^{-2} \cdot \mathrm{s}^{-1}$ of white fluorescent light for $12-\mathrm{h}$ days timed to coincide with day temperatures. Thirty achenes were sown in each of the four petri dishes per treatment in 2005; in 2006, because of limited seed availability, only 15 achenes were sown in each of four petri dishes per treatment. Germinated achenes were counted daily or every second day for 8 weeks.

Statistical analysis. Data were evaluated using analysis of variance $(\mathrm{R}$ Development Core Team, 2006). For all experiments, the response variable was the germination proportion, which was defined as the number of germinated achenes divided by the number of viable achenes. Germination was defined by emergence of radical and hypocotyl. Based on the binomial distribution of the germination proportions, the data were arcsinsquare root transformed (Snedecor and Cochran, 1989). Our sources of variation were fixed in all experiments. The third experiment was conducted in both 2005 and 2006. Because of heterogeneity of variance between the 2 years of the third experiment, the data for each year were analyzed and discussed separately. For figures, the germination proportions were backtransformed and reported as percentages. Multiple mean comparisons were conducted using Fisher's protected least significant difference test. Means were considered significant at the $P<$ 0.05 level.

\section{Results and discussion}

EXPT. 1: PERIGYNIA REMOVAL AND LIght exposure. Perigynia removal and light exposure significantly increased germination (Fig. 1). Intact perigynia and darkness inhibited germination. Highest percent germination occurred when the perigynia were removed and when the achenes were exposed to white light (Fig. 1), although germination was still below $35 \%$. Previous research showed many Carex species are either light obligate or greatly benefit from light after sowing (Kettenring et al., 2006; Schutz and Rave, 1999). From a germination mean of $21 \%$ in light, payson's sedge (Carex paysonis) germinated at less than $1 \%$ in complete darkness, and also when buried at a mere $0.5 \mathrm{~cm}$, germination was greatly reduced (Haggas et al., 1987). Ebony sedge achenes germinated at $75.8 \%$ under fluorescent lights but only at $0.8 \%$ in darkness (Amen and Bonde, 1964). In a German study of 32 temperate Carex species, $2.07 \%$ of all unstratified achenes germinated in darkness under a diurnally fluctuating temperature regime (Schutz and Rave, 1999).

Germination of forest Carex species is not only inhibited by complete darkness, but it is also inhibited by dense plant canopies that reduce the red-to-far red ratio (Kettenring et al., 2006) and factors that partially reduce irradiance such as leaf litter and soil coverage. In a field study of two European wet-forest species, remote sedge and elongated sedge germinated in a deciduous forest almost exclusively during late April and early May before the canopy regenerated (Schutz, 1997a). In another field study, leaf litter inhibited the germination of fibrousroot sedge (Carex communis), broadleaf sedge (Carex platyphylla), and back's

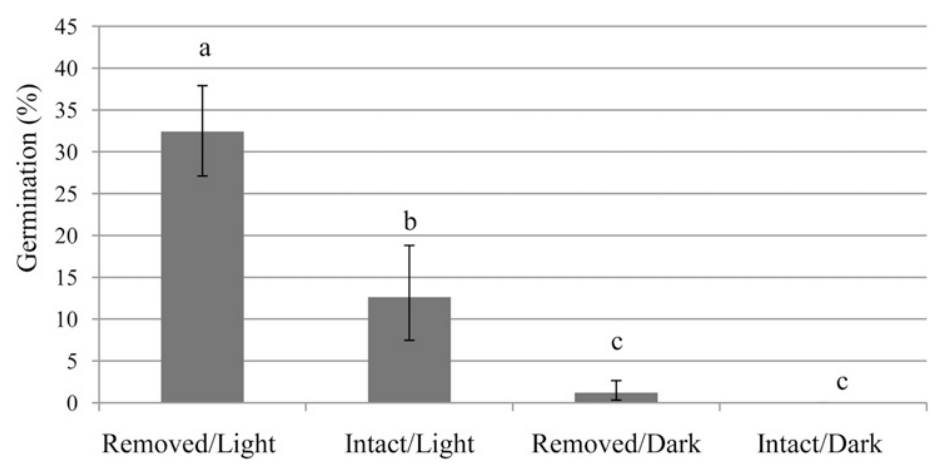

Fig. 1. The effect of perigynia removal and light exposure on germination of 2006 pennsylvania sedge achenes at the University of Minnesota, MN. Half of the achenes had their perigynia removed, while the other half were left intact. Achenes were germinated under white fluorescent light or in darkness. Error bars represent SE. Mean values labeled with different lowercase letters were significantly different according to Fisher's protected least significant difference test at $P \leq 0.05$ ( $n=12$ viable achenes, eight replications). 
sedge (Carex backii) (Vellend et al., 2000). Pennsylvania sedge capitalizes on disturbances that increase general irradiance levels and the red-to-far red ratio such as canopy openings (Collins and Good, 1987) [e.g., clear-cutting of jack pine (Pinus banksiana) forests and fire (Abrams and Dickmann, 1984)] and exotic earthworm consumption of leaf litter (Hale et al., 2008). Achenes may have evolved to germinate best in areas of high irradiance and favorable red-to-far red ratios. This would allow pennsylvania sedge to germinate during spring before the forest canopy closes and during periods in which competitive foliage is scarce.

The benefit of perigynia removal on germination appears to be species specific. Japanese sedge (Carex kobomugi), a coastal sand dune sedge, required scarification of the achene in addition to perigynia removal (Ishikawa et al., 1993). In contrast, 12 North American wetland Carex species germinated to high percentages without perigynia removal or scarification (Kettenring and Galatowitsch, 2007a). This variability between closely related species within the genus Carex is common (Kettenring and Galatowitsch, 2007a). No study has been conducted to determine why an intact perigynium may reduce achene germination; however, Jones et al. (2004) suggested that the perigynia may reduce the light reaching the achene.

EXPT. 2: STORAGE TEMPERATURE, DURATION, AND $\mathbf{G A}_{3}$. Presowing storage temperature and duration affected germination, but $\mathrm{GA}_{3}$ pretreatment did not. Storage at $22{ }^{\circ} \mathrm{C}$ for 16 weeks increased germination percentage in comparison with achenes stored at $4{ }^{\circ} \mathrm{C}$ for either 4 or 8 weeks or for achenes stored at $22^{\circ} \mathrm{C}$ for 4 weeks (Fig. 2). (The number of storage weeks does not include the initial 5 weeks of warm storage after harvest.) It appears that length of storage is more important than storage temperature for pennsylvania sedge germination. Optimum storage conditions appear to be habitat specific. Wetland sedges benefit from cold, wet storage (Budelsky and Galatowitsch, 1999), while prairie (Larson and Stearns, 1990) and forest sedges respond to dry-warm storage (Schutz, 1997b). While pennsylvania sedge benefited from an extended period of dry storage under either cold or warm temperatures before sowing, it is unlikely to benefit from cold, wet storage conditions because of its habitat restrictions. Pennsylvania sedge typically inhabits dry to mesic woods and prairies (Hipp, 2008).

Gibberellic acid pretreatment had no effect on pennsylvania sedge germination. Our $\mathrm{GA}_{3}$ results were not dispositive because we tested only one concentration. However, $\mathrm{GA}_{3}$ failed to stimulate germination in two previous studies on Carex species (Amen and Bonde, 1964; McDonough, 1969).

EXPT. 3: STORAGE, COLD STRATIFICATION, AND SOWING TEMPERATURE. In the 2005 experiment, an interaction occurred between warm storage duration and cold stratification duration (Table 2), which can be explained by the variable response to 1 and 2 months of warm storage (Fig. 3). Non-stratified achenes and 2-month stratified achenes did not exhibit significantly improved germination if they were previously exposed to a warm storage period of 2 months as opposed to 1 month. In contrast, when the warm storage period was increased from 1 month to 2 months, germination of 1-month stratified achenes increased significantly across all sowing temperatures (Fig. 3). Two months of warm storage may have alleviated physiological dormancy enough to allow for maximum germination after only 1 month of cold stratification. Overall in 2005, achenes that were cold-stratified for 2 months and germinated at a constant $22^{\circ} \mathrm{C}$ or fluctuating $26^{\circ} \mathrm{C}$ day $/ 18{ }^{\circ} \mathrm{C}$ night temperatures had the most consistent germination, all exceeding $80 \%$ (Fig. 3 ). Sowing temperature of $30^{\circ} \mathrm{C}$ day / $14{ }^{\circ} \mathrm{C}$ night resulted in low germination (Fig. 3).

A three-way interaction occurred during the 2006 experiment between storage, stratification, and sowing temperature (Table 2) due to the inconsistent response of achenes that

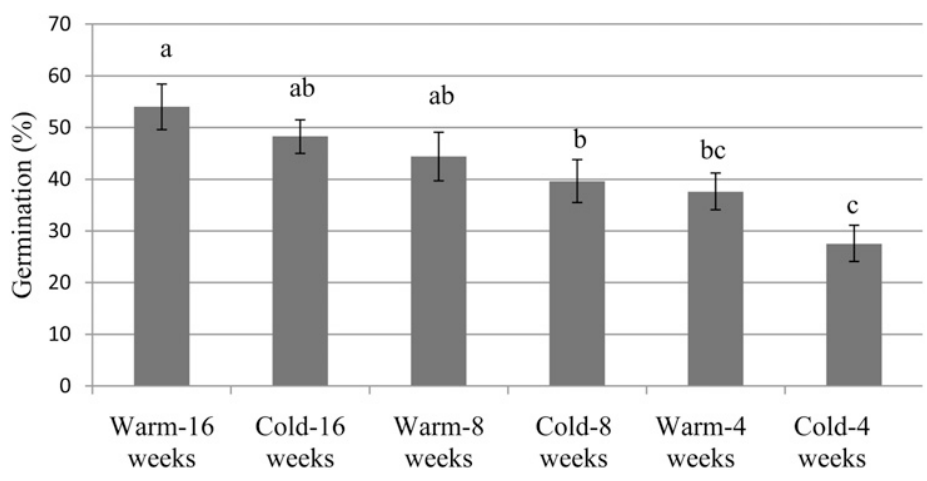

Fig. 2. The effect of storage temperature and storage duration on germination of 2006 pennsylvania sedge achenes. Achenes were stored at $22^{\circ} \mathrm{C}$ for 5 weeks after harvest and then subjected to storage at $22^{\circ} \mathrm{C}$ (warm) or $4{ }^{\circ} \mathrm{C}$ (cold) for an additional 4, 8, or 16 weeks. Error bars represent SE. Mean values labeled with different lowercase letters were significantly different according to Fisher's protected least significant difference test at $P \leq 0.05$ ( $n=12$ viable achenes, eight replications $) ;\left(1.8 \times{ }^{\circ} \mathrm{C}\right)+32={ }^{\circ} \mathrm{F}$.

Table 2. Summary of analysis of variance results for the effects of storage, cold stratification duration, and sowing temperature on 2005 and 2006 pennsylvania sedge germination.

\begin{tabular}{lccc}
\hline & & \multicolumn{2}{c}{ Significance } \\
\cline { 3 - 4 } Source & df & 2005 & 2006 \\
\hline Storage & 1 & $* * *$ & $*$ \\
Stratification & 2 & $*$ & $*$ \\
Temperature & 2 & $* * *$ & NS \\
Storage $\times$ stratification & 2 & $* *$ & NS \\
Storage $\times$ temperature & 2 & NS & NS \\
Stratification $\times$ temperature & 4 & NS & * \\
Storage $\times$ stratification $\times$ temperature & 4 & NS
\end{tabular}

NS, ${ }^{*},{ }^{* *},{ }^{* * *}$ Nonsignificant or significant at $P \leq 0.05,0.01$, or 0.001 , respectively. 
were stratified for 1 month. With the exception of one treatment, achenes that had been cold-stratified for 2 months exhibited the most consistent germination (Fig. 4). Germination was much lower for all treatments in 2006 than in 2005.

Cold stratification significantly increased germination in 28 of 32 European Carex species (Schutz and Rave, 1999). Stratification also increased the germination of most of the 12 North American wetland species studied across many different germination temperature regimes (Kettenring and Galatowitsch, 2007a).

In our experiments, the germination percentage ranged from 57\% to $96 \%$ in 2005 and from $31 \%$ to $67 \%$ in 2006. These variable results are consistent with previous studies of North American sedges (Kettenring and Galatowitsch, 2007a, 2007b). The variation between years may be

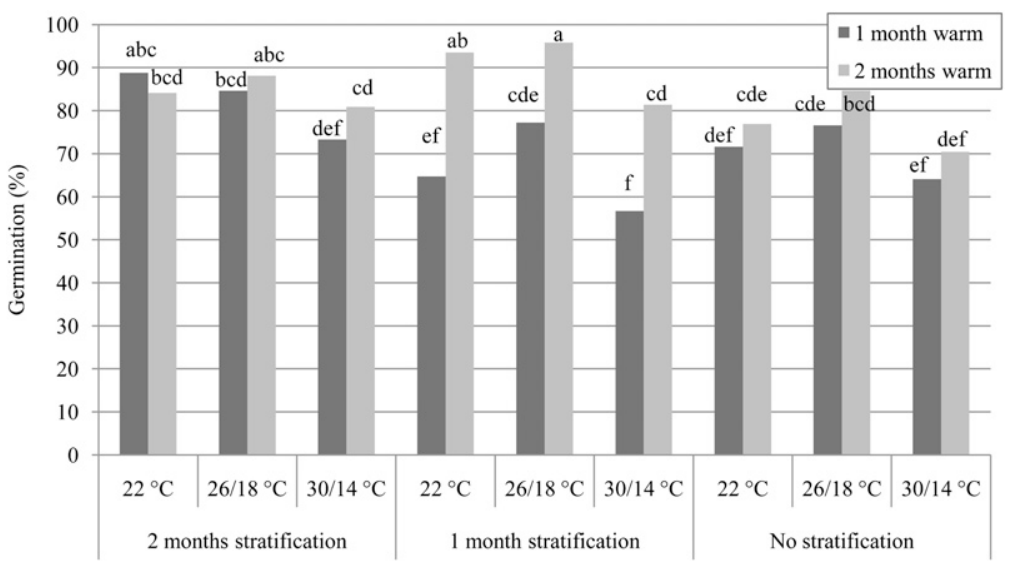

Fig. 3. The effect of warm storage duration, cold stratification, and sowing temperature on 2005 pennsylvania sedge achene germination. The black and gray columns depict 1 and 2 months of after-ripening, respectively, at $\approx 22^{\circ} \mathrm{C}$. Achenes were cold-stratified at $4^{\circ} \mathrm{C}$ for 0,1 , or 2 months. For each stratification period, data are presented for sowing temperatures of either constant $22{ }^{\circ} \mathrm{C}$ or fluctuating day and night temperatures of $26^{\circ} \mathrm{C}$ day $/ 18^{\circ} \mathrm{C}$ night or $30^{\circ} \mathrm{C}$ day $/ 14$ ${ }^{\circ} \mathrm{C}$ night. Mean values labeled with different lowercase letters were significantly different according to Fisher's protected least significant difference test at $P \leq \mathbf{0 . 0 5}$ ( $n=25$ viable achenes, eight replications); $\left(1.8 \times{ }^{\circ} \mathrm{C}\right)+32={ }^{\circ} \mathrm{F}$.

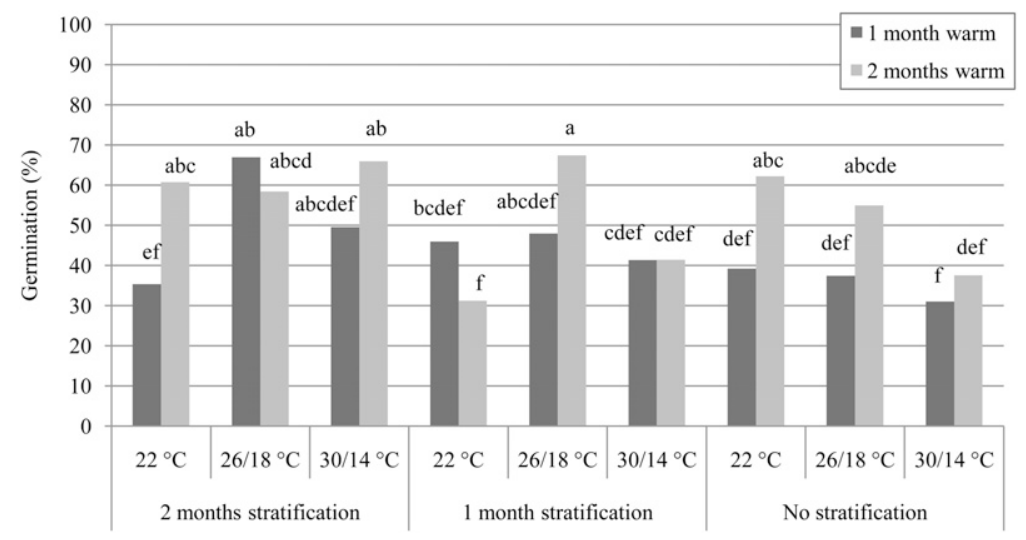

Fig. 4. The effect of warm storage duration, cold stratification, and sowing temperature on 2006 pennsylvania sedge achene germination. The black and gray columns depict 1 and 2 months of after-ripening, respectively, at $\approx 22^{\circ} \mathrm{C}$. Achenes were cold-stratified at $4^{\circ} \mathrm{C}$ for 0,1 , or 2 months. For each stratification period, data are presented for sowing temperatures of either constant $22{ }^{\circ} \mathrm{C}$ or fluctuating day and night temperatures of $26^{\circ} \mathrm{C}$ day $/ 18{ }^{\circ} \mathrm{C}$ night or $30{ }^{\circ} \mathrm{C}$ day $/ 14$ ${ }^{\circ} \mathrm{C}$ night. Mean values labeled with different lowercase letters were significantly different according to Fisher's protected least significant difference test at $P \leq \mathbf{0 . 0 5}$ $\left(n=12\right.$ viable achenes, eight replications); $\left(1.8 \times{ }^{\circ} \mathrm{C}\right)+32={ }^{\circ} \mathrm{F}$. attributed to several factors. Schutz and Rave (2003) reported a large variation in germination between four populations of elongated sedge that were only $15 \mathrm{~km}$ apart. Population differences may also explain our result. In the 2006 stratification experiment, different achene sources were necessary due to limited availability. Thus, the variation in results between the 2 years may be genetic. In addition, variation between the same populations may occur between consecutive years (Schutz and Rave, 2003). Different climatic conditions during ripening cannot be discounted. Achenes collected in 2006 appeared to have more smut infestation than those collected the previous year.

\section{Conclusions}

Our experiments outline several treatments that enhance pennsylvania sedge germination. After harvest, achenes should be warm-stored or after-ripened for an extended period. No loss of germination percentage was observed as after-ripening increased up to 21 weeks at $\approx 22^{\circ} \mathrm{C}$. Eight weeks of cold stratification in conjunction with after-ripening yielded more consistent germination. Removal of the perigynia before cold stratification and incubation in white light also enhanced germination. Using these treatments, we believe pennsylvania sedge can be effectively produced from seed for restoration or horticultural purposes.

\section{Literature cited}

Abrams, M.D. and D.I. Dickmann. 1984. Floristic composition before and after prescribed fire on a jack pine clear-cut site in northern lower Michigan. Can. J. For. Res. 14(5):746-749.

Amen, R.D. and E.K. Bonde. 1964. Dormancy and germination in alpine Carex from the Colorado front range. Ecology 45(4):881-884.

Baskin, C.C. and J.M. Baskin. 1998. Seeds: Ecology, biogeography, and evolution of dormancy and germination. Academic Press, San Diego, CA.

Baskin, C.C. and J.M. Baskin. 2004. Determining dormancy-breaking and germination requirements from the fewest seeds, p. 162-179. In: E.O. Guerrant, K. Havens, and M. Maunder (eds.). Ex situ plant conservation: Supporting species survival in the wild. Island Press, Washington, DC. 
Bernard, J.M. 1990. Life history and vegetative reproduction in Carex. Can. J. Bot. 68(7):1441-1448.

Brandel, M. and W. Schutz. 2005. Temperature effects on dormancy levels and germination in temperate forest sedges (Carex). Plant Ecol. 176(2):245-261.

Budelsky, R.A. and S.M. Galatowitsch. 1999. Effects of moisture, temperature, and time on seed germination of five wetland Carices: Implications for restoration. Restor. Ecol. 7(1):86-97.

Collins, S.L. and R.E. Good. 1987. Canopy-ground layer relationships of oak-pine forests in the New Jersey Pine Barrens. Amer. Midl. Nat. 117(2):280-288.

Crins, W.J. and P.W. Ball. 1983. The taxonomy of the Carex pensylvania complex (Cyperaceae) in North America. Can. J. Bot. 61(6):1692-1717.

Darke, R. 2007. The encyclopedia of grasses for livable landscapes. Timber Press, Portland, OR.

Fulbright, T.E., E.F. Redente, and A.M. Wilson. 1983. Germination requirements of green needlegrass (Stipa viridula Trin.). J. Range Mgt. 36(3):390-394.

Gleason, H.A. and A. Cronquist. 1991. Manual of vascular plants of northeastern United States and adjacent Canada. 2nd ed. New York Botanical Garden Press, Bronx, NY.

Grabe, D.F. 1970. Tetrazolium testing handbook for agricultural seeds: Contribution no. 29 to the handbook on seed testing. Assn. Official Seed Analysts, Lincoln, NE.

Greipsson, S. 2001. Effects of stratification and $\mathrm{GA}_{3}$ on seed germination of a sand stabilizing grass Leymus arenarius used in reclamation. Seed Sci. Technol. 29(1):1-10.

Grimes, J.P., G. Mason, A.V. Curtis, J. Rodman, S.R. Band, M.A.G. Mowforth, A.M. Neal, and S. Shaw. 1981. A comparative study of germination characteristics in a local flora. J. Ecol. 69(3): 1017-1059.
Haggas, L., R.W. Brown, and R.S. Johnston. 1987. Light requirement for seed germination of payson sedge. J. Range Mgt. 40(2):180-184.

Hagon, M.W. 1976. Germination and dormancy of Themeda australis, Danthonia spp., Stipa bigeniculata, and Bothriochloa macra. Aust. J. Bot. 24(3):319-327.

Hale, C.M., L.E. Frelich, and P.B. Reich. 2008. Exotic earthworm effects on hardwood forest floor, nutrient availability and native plants: A mesocosm study. Oecologia 155(3):509-518.

Hipp, A.L. 2008. Field guide to Wisconsin sedges: An introduction to the genus Carex (Cyperaceae). University of Wisconsin Press, Madison, WI.

Hoag, J.C., R.K. Dumroese, and M.E. Sellers. 2001. Perigynium removal and cold, moist stratification improve germination of Carex nebrascensis (Nebraska sedge). Native Plants J. 2(1):63-66.

Ishikawa, S., A. Furukawa, T. Okuda, and T. Oikawa. 1993. Germination requirements in Carex kobomugi (Sea Isle). J. Plant Res. 106(3):245-248.

Jones, K.L., B.A. Roundy, N.L. Shaw, and J.R. Taylor. 2004. Environmental effects on germination of Carex utriculata and Carex nebrascensis relative to riparian restoration. Wetlands 24(2): 467-479.

Kettenring, K.M. and S.M. Galatowitsch. 2007a. Tools for Carex regeneration in freshwater wetlands: Understanding dormancy loss and germination temperature requirements. Plant Ecol. 193(2):157169.

Kettenring, K.M. and S.M. Galatowitsch. $2007 \mathrm{~b}$. Temperature requirements for dormancy break and seed germination vary greatly among 14 wetland Carex species. Aquat. Bot. 87(3):209-220.

Kettenring, K.M., G. Gardner, and S.M. Galatowitsch. 2006. Effect of light on seed germination of eight wetland Carex species. Ann. Bot. (Lond.) 98(4):869-874.

Larson, J.L. and F.W. Stearns. 1990. Factors influencing seed germination in
Carex scoparia Schk. Wetlands 10(2): 277-283.

McDonough, W.T. 1969. Effective treatments for the induction of germination in mountain rangeland species. Northwest Sci. 43:18-22.

Mottl, L.M., C.M. Mabry, and D.R. Farrar. 2006. Seven-year survival of perennial herbaceous transplants in temperate woodland restoration. Restor. Ecol. 14(3):330-338.

R Development Core Team. 2006. R: A language and environment for statistical computing. R Foundation for Statistical Computing, Vienna, Austria.

Rogis, C., L.R. Gibson, A.D. Knapp, and R. Horton. 2004. Enhancing germination of eastern gamagrass seed with stratification and gibberellic acid. Crop Sci. 44(2):549-552.

Schutz, W. 1997a. Are germination strategies important for the ability of cespitose wetland sedges (Carex) to grow in forests? Can. J. Bot. 75(10):1692-1699.

Schutz, W. 1997b. Primary dormancy and annual dormancy cycles in seeds of six temperate wetland sedges. Aquat. Bot. 59(1):75-85.

Schutz, W. and G. Rave. 1999. The effect of stratification and light on the seed germination of temperate sedges (Carex) from various habitats and implications for regenerative strategies. Plant Ecol. 144(2): 215-230.

Schutz, W. and G. Rave. 2003. Variation in seed dormancy of the wetland sedge, Carex elongata, between populations and individuals in two consecutive years. Seed Sci. Res. 13(4):315-322.

Snedecor, G.W. and W.G. Cochran. 1989. Statistical methods. 8th ed. Iowa State Univ. Press, Ames, IA.

Vellend, M., M.J. Lechowicz, and M.J. Waterway. 2000. Germination and establishment of forest sedges (Carex, Cyperaceae): Tests for home-site advantage and effects of leaf litter. Amer. J. Bot. 87(10): 1517-1525. 